\title{
Degradation Sulfamethoxazole by Chlorination in Water Distribution Systems: Kinetics, Toxicity, and Antibiotic Resistance Genes
}

\section{Luo Xu}

University of Shanghai for Science and Technology

congli ( $\sim$ congil@aliyun.com )

University of Shanghai for Science and Technology

Guozijian Wei

University of Shanghai for Science and Technology

Jie Ji

University of Shanghai for Science and Technology

\section{Eric Lichtfouse}

Aix-Marseille Universite de Provence: Aix-Marseille Universite

\section{Andreina García}

Universidad de Chile

Yunshu Zhang

University of Shanghai for Science and Technology

Kai Zhang

University of Shanghai for Science and Technology

\section{Research Article}

Keywords: Sulfamethoxazole (SMX), Water distribution system (WDS), Chlorination, Kinetics, Toxicity, Antibiotic resistance genes (ARGs)

Posted Date: November 23rd, 2021

DOI: https://doi.org/10.21203/rs.3.rs-1048577/v1

License: (c) (i) This work is licensed under a Creative Commons Attribution 4.0 International License.

Read Full License 


\section{Degradation Sulfamethoxazole by Chlorination in Water Distribution} Systems: Kinetics, Toxicity, and Antibiotic Resistance Genes Luo $\mathrm{Xu}^{1}$, Cong $\mathrm{Li}^{1 *}$, Guozijian Wei ${ }^{1}$, Jie $\mathrm{Ji}^{1}$, Eric Lichtfouse ${ }^{2}$, Andreina García ${ }^{3}$, Yunshu Zhang ${ }^{1}$, Kai Zhang ${ }^{1}$

${ }^{1}$ School of Environment and Architecture, University of Shanghai for Science and Technology, Shanghai, 200433, China.

${ }^{2}$ Aix-Marseille Univ, CNRS, IRD, INRAE, Coll France, CEREGE, Avenue Louis Philibert, Aix en Provence, 13100, France.

${ }^{3}$ Advanced Mining Technology Center (AMTC), Universidad de Chile, Av Tupper 2007, Santiago 8370451, Chile

Luo Xu, Email address: xuluo511324@163.com

Cong Li, Email address: congil@aliyun.com

Guozijian Wei, Email address: weiguozijian@,foxmail.com

Jie Ji, Email address: jijie_1102@,163.com

Eric Lichtfouse, Email address: eric.lichtfouse@inrae.fr

Andreina García, Email address: andreina.garcia@amtc.cl

Yunshu Zhang, Email address: zhangys@,usst.edu.cn

Kai Zhang, Email address: Kevin_ZhangK@126.com

*Corresponding author

Email addresses: congil@aliyun.com (C. Li) 


\section{Declarations}

Ethics approval This research does not include animal and human experiments.

\section{Consent to participate This research does not include human experiments.}

Consent for publication The author confirms (1) that the work described has not been published before; (2) that it is not under consideration for publication elsewhere; (3) that its publication has been approved by all co-authors, if any; and (4) that its publication has been approved (tacitly or explicitly) by the responsible authorities at the institution where the work is carried out.

The author agrees to publication in the Journal indicated below and also to publication of the article in English by Springer in Springer's corresponding Englishlanguage journal.

The copyright to the English-language article is transferred to Springer effective if and when the article is accepted for publication. The author warrants that his/her contribution is original and that he/she has full power to make this grant. The author signs for and accepts responsibility for releasing this material on behalf of any and all co-authors. The copyright transfer covers the exclusive right to reproduce and distribute the article, including reprints, translations, photographic reproductions, microform, electronic form (offline, online) or any other reproductions of similar nature.

Data availability All data generated or analyzed during this study are included in this published article and its supplementary information files.

Conflict of interests The authors declare no competing interests. 
Science Foundation of China (No. 51778565) and the Shanghai Natural Science Foundation (No. 20ZR1438200). design. Material preparation, data collection, and detection were performed by Luo Xu, Guozijian Wei, and Jie Ji. The first draft of the manuscript was written by Luo Xu, and data analysis were contributed by Luo Xu, Yunshu Zhang and Kai Zhang. Search

60 activity planning and direction were contributed by Cong Li, Eric Lichtfouse, and 61 Andreina García. 
Abstract: Sulfamethoxazole (SMX) is a veterinary drugs and feed additives,

which has been frequently detected in surface waters in recent years. This paper investigated the kinetics, evolution of toxicity and antibiotic resistance genes (ARGs) of SMX in reactions with free chlorine (FC) to evaluate the fate of SMX in batch reactors and water distribution systems (WDS). In the range of investigated $\mathrm{pH}(6.3-$ 9.0), the SMX degradation had the fastest rate at close to neutral $\mathrm{pH}$. The chlorination of SMX could be described by the first-order kinetics, with specific second-order rate constants in batch reactors of $(2.23 \pm 0.07) \times 10^{2} \mathrm{M}^{-} \mathrm{s}$ and $(5.04 \pm 0.30) \times 10^{1} \mathrm{M}^{-} \mathrm{s}^{-}$ for $\mathrm{HClO}$ and $\mathrm{ClO}^{-}$, respectively. And in WDS of $(1.76 \pm 0.07) \times 10^{2} \mathrm{M}^{-} \mathrm{s}^{-}$and $(4.06$ $\pm 0.62) \times 10^{1} \mathrm{M}^{-} \mathrm{s}^{-}$, respectively. The SMX degradation rate was also affected by pipe material, and the rate followed the order: stainless-steel pipe (SS) $>$ ductile iron pipe (DI) $>$ polyethylene pipe (PE). The flow rate from 0.7 to $1.5 \mathrm{~m} / \mathrm{s}$ led to an increase of SMX degradation rate in DI, but the increase was limited. In addition, SMX could increase the toxicity of water initially, yet the toxicity reduced to the level of tap water after 2 hours chlorination. The relative abundance of ARGs (sull and sul2) of tap water samples was significantly increased under different conditions including only use SMX, chlorination products of SMX, or pretreatment with SMX followed by chlorination.

Key words: Sulfamethoxazole (SMX); Water distribution system (WDS); Chlorination; Kinetics; Toxicity; Antibiotic resistance genes (ARGs)

\section{Introduction}

Since penicillin by Alexander Fleming was discovered in 1928, antibiotics have 
been widely used to prevent human and animal infectious diseases (Huang et al. 2020, Wang et al. 2020, Zhang et al. 2015a). However, $60-80 \%$ of antibiotics are not absorbed after entering human and animal bodies but directly discharged from the body through feces or urine (Chen et al. 2017), which has become the main source of antibiotic residues in the environment. In addition, aquaculture industry (Tian et al. 2013), medical and pharmaceutical wastewater (Gobel et al. 2005, Lindberg et al. 2004) is also an important source of environmental antibiotic residue. Antibiotics are considered to be "pseudo persistent" pollutants because they continue to enter the ecosystem (Gulkowska et al. 2008), which has aroused great concern because of they may impose a potential risk to the non-target species (Chen et al. 2011).

Sulfonamides (SAs) are one of the most widely used antibiotics in the world (Gaffney et al. 2016), with more than 20,000 tons of SAs (excluding drugs used as herbicides) are introduced into the biosphere each year (Qiu et al. 2016). As a kind of fairly water-soluble polar compounds, SAs are weakly degraded in the nature, thus they can easily enter surface runoff or be leached into the groundwater. Luo et al.(Luo et al. 2011) reported that the concentration of trimethoprim, trimethoprim, sulfamethoxazole, sulfachloropyridazine in Haihe Rive was $(1.2 \pm 0.8) \times 10^{2} \mathrm{ng} / \mathrm{L},(1.2 \pm 0.8) \times 10^{2} \mathrm{ng} / \mathrm{L}$, $(1.7 \pm 1.0) \times 10^{2} \mathrm{ng} / \mathrm{L}$ and $(1.8 \pm 1.4) \times 10^{2} \mathrm{ng} / \mathrm{L}$, respectively. A survey (Jiang et al. 2011) of the Huangpu River found that the concentration of trimethoprim, sulfadiazine, sulfamethoxazole, sulfachloropyridazine was $62.39 \mathrm{ng} / \mathrm{L}, 40.55 \mathrm{ng} / \mathrm{L}, 623.27 \mathrm{ng} / \mathrm{L}$, $58.29 \mathrm{ng} / \mathrm{L}$, respectively. $\mathrm{Li}$ et al.(Li et al. 2017a) reported that the concentration of oxytetracycline reached $600 \mathrm{ng} / \mathrm{L}$ in tap water in Hong Kong. Therefore, the existence 
of antibiotics is not only limited to the environmental water of nature, but also exists in the drinking water related to human beings. SAs concentrations in natural water are quite low, ranging from nanograms to micrograms per liter $(\mathrm{ng} / \mathrm{L}-\mu \mathrm{g} / \mathrm{L})($ Zhang et al. 2018b), but it still has ecotoxicity at this level (Fent et al. 2006). For example, SAs can damage the human immune system, pose skin allergic reactions (Choquet-Kastylevsky et al. 2002) and even carcinogen risk (Shao et al. 2005), inhibit the germination of plants (Migliore et al. 2003), and case ecological bioaccumulation in aquatic organisms (Peiris et al. 2017). Furthermore, they can promote the microbial genetic variation (Jeong et al. 2010), which may lead to the emergence of ARGs and antibiotic-resistant bacteria (Zheng et al. 2017). Guo et al.(Guo et al. 2014) investigated the ARGs levels in the Yangtze River Delta of China and detected the existence of 10 ARGs in the source waters of the 7 water treatment plants, among which the relative abundance of ARGs sul1, sul2, tet (c) and tet $(g)$ is the highest, total concentrations of ARGs were above $10^{5}$ copies / $\mathrm{mL}$. The sull and sul2 were also the most frequently detected sulfonamide ARGs in surface waters in Germany and Australia (Stoll et al. 2012). ARGs and antibiotic-resistant bacteria could enhance the potential for both new and old diseases to emerge (Mulvey \&Simor 2009).

Various technologies were used to remove or degrade SAs in water, including biodegradation (Chen \&Xie 2018, Yu et al. 2018), activated carbon and porous resin adsorption (Choi et al. 2008, Yang et al. 2011), membrane filtration (Rosman et al. 2018), free chlorination (Gaffney et al. 2016) and advanced oxidation (Beltran et al. 2008, Guo et al. 2015b). Among these methods, free chlorination is regarded as one of 
the most effective technologies due to its low price, continuous disinfection, wide application scope and high oxidation efficiency for a variety of organic compounds (Dong et al. 2019, Dong et al. 2017). Nassar et al. (Nassar et al. 2018) have shown that FC can react with SAs in the first-order. Dodd et al. (Dodd \&Huang 2004) established a degradation model of SMX by chlorine under different $\mathrm{pH}$ based on pseudo secondorder kinetics, and detected the chlorination products by using GC-MS and LC-MS derivatization methods and proposed the degradation pathway (Dodd \&Huang 2004, Gaffney et al. 2016). However, most SAs chlorination studies were generally conducted under lab-scale static conditions (e.g., beakers with buffered water, or deionized). The SAs chlorination and the potential influence of chlorination on ARGs in dynamic water distribution system (WDS) has been scarcely studied.

Sulfamethoxazole (SMX, CAS Number 723-46-6) is a typical SAs (Yao et al. 2018), which is mainly used as veterinary drugs and feed additives and its selected chemical properties were showed in Fig. S1. This study mainly includes the following aspects: (1) Investigate the relationship between the SMX chlorination and the concentrations of $\mathrm{FC}, \mathrm{pH}$, flow rate and pipe materials in batch reactor and WDS; (2) Determine the kinetics of SMX chlorination by FC, and analyze the difference between its degradation in batch reactor and WDS; (3) Evaluate the evolution of toxicity during the SMX chlorination in WDS; (4) Investigate the production of antibiotic resistance genes of pipeline bacteria under the exiting condition of only use SMX, chlorination products of SMX, or pretreatment with SMX followed by chlorination.

\section{Materials and methods}




\subsection{Experimental Materials}

SMX ( $\geq 98 \%$ ) was purchased from TCI (Shanghai, China), and FC stock solutions were prepared by dilution of commercial $5.5-6.5 \%$ sodium hypochlorite solution from Aladdin (Shanghai, China). N,N-diethyl-p-phenylenediamine (DPD) was purchased from Hach Company (Loveland, Colorado, USA) and it was used to measure chlorine concentration. HPLC-grade acetonitrile (ACN), methanol (MeOH) and phosphoric acid $\left(\mathrm{H}_{3} \mathrm{PO}_{4}\right)$ were purchased from Sigma Aldrich (Shanghai, China). Other reagents, including dibasic sodium phosphate $\left(\mathrm{Na}_{2} \mathrm{HPO}_{4}, \mathrm{AR}\right.$ grade), sodium dihydrogen phosphate $\left(\mathrm{NaH}_{2} \mathrm{SO}_{4}, \mathrm{AR}\right.$ grade) and sodium thiosulfate $\left(\mathrm{Na}_{2} \mathrm{~S}_{2} \mathrm{O}_{3}, \mathrm{CP}\right.$ grade) was purchased from Sinopharm Chemical Reagent (Shanghai, China). The bacteria and reactivation reagent were from Hamamatsu Photonics (Beijing, China) were used to evaluate toxicity. The purified water obtained from a Millipore Milli-Q apparatus and tap water obtained from Hangzhou City.

\subsection{Batch reactor and WDS}

The degradation experiments of SMX were conducted in a batch reactor and WDS with using sodium hypochlorite $(\mathrm{NaClO})$ as a disinfectant. Batch experiments were conducted in $500 \mathrm{~mL}$ brown glass beakers to exclude the influence of potential light (Fig. S2 (a)). The WDS system had three separate loops (each loop is $150 \mathrm{~mm}$ in diameter and $80 \mathrm{~m}$ in length), made of polyethylene pipe (PE), ductile iron pipe (DI), and stainless-steel pipe (SS). Each loop was equipped with an online monitoring system, circulation pump (which can adjust the flow rate), chemical injection ports and sampling tap, and each loop could be operated independently (Fig. S2 (b), (c) and 
(d)).

2.3. Degradation experiments of SMX

Using fresh tap water washed each WDS loop at speed of $1 \mathrm{~m} / \mathrm{s}$ for $20 \mathrm{~min}$ before WDS experiments. In the WDS experiments, experimental water was the tap water and its characteristics are shown in Table S1. The initial concentration of SMX was $200 \mu \mathrm{g} / \mathrm{L}$, and experiments temperature was stabilized at $25^{\circ} \mathrm{C}$ by an automatic control system. A 5\% sodium hypochlorite solution was added in loops through chemical injection ports, until ultimately concentration of free chlorine reached the required values $(0.4,0.6 .0 .8$ and $1.0 \mathrm{mg} / \mathrm{L})$. The $\mathrm{pH}$ levels $(6.6,7.0,7.4,7.8$ and 8.2$)$ and flow rates $(0.7,1.0,1.3$ and $1.5 \mathrm{~m} / \mathrm{s})$ were adjusted by phosphate buffer and circulation pump, respectively. In addition, the effects of pipe materials were examined by using three kinds of pipes (PE, DI, SS) due to they were commonly used in drinking water distribution system in China. In the batch reactors experiments, the $\mathrm{pH}$ levels were set as $6.3,6.6,6.9,7.2,7.5,7.8,8.1,8.4,8.7$ and 9.0, and other conditions were consistent with WDS experiments. $10 \mathrm{~mL}$ samples were collected at $0,5,10,15,20,25,30,35$ and 40 min respectively, and then $1 \mathrm{~mL}$ of $100 \mathrm{mg} / \mathrm{L} \mathrm{Na}_{2} \mathrm{~S}_{2} \mathrm{O}_{3}$ (as quenching agent) was immediately added to stop further reaction.

2.4. Determination of antibiotic concentration

The SMX in each sample was quantified by an Agilent 1200 Series HPLC, which equipped with a Zorbax Eclipse XDB-C18 column $(4.6 \mathrm{~mm} \times 150 \mathrm{~mm}, 5 \mu \mathrm{m})$ and a UV detector (G1314B, Agilent Technologies, Santa Clara, CA, U.S.). The column temperature was set at $30{ }^{\circ} \mathrm{C}$ and injection sample volume was $20 \mu \mathrm{L}$. The detection 
wavelength was set at $270 \mathrm{~nm}$. Pure acetonitrile and $1 \%(\mathrm{v} / \mathrm{v})$ phosphoric acid with the ratio of $80: 20$ was the mobile phase, and the flow was $0.8 \mathrm{~mL} / \mathrm{min}$.

\subsection{Toxicity assessment of SMX degradation}

Microtox method (the international procedure ISO 11348-3) (Buysse et al. 1989) was used to evaluate the toxic evolution of a SMX solution during chlorination in WDS (DI), which was based on the inhibition of the luminescence by $V$. fischeri (Barhoumi et al. 2016) marine bacteria with 15 min exposure. A multiscan spectrum M200 PRO (Tecan, Austria) was used. In order to prevent the inactivation of $V$. fischeri by FC, the FC in each water sample was quenched with $0.2 \mathrm{~mol} / \mathrm{L} \mathrm{Na}_{2} \mathrm{~S}_{2} \mathrm{O}_{3}$ and $\mathrm{Na}_{2} \mathrm{~S}_{2} \mathrm{O}_{3}$ itself did not inhibit $V$. fischeri (Wei et al. 2011). The calculation formula of the inhibition of light emissions was: inhibition $=\left(\mathrm{I}_{0}-\mathrm{I}\right) / \mathrm{I}_{0}$, where $\mathrm{I}$ and $\mathrm{I}_{0}$ was the luminescent intensity of samples at different times and the luminescent intensity of the blank solution, respectively.

\subsection{DNA extraction}

Four group experiments were set up in this section, which were carried out in WDS (DI). A group represented the tap water samples that were placed for 6 days, as blank control; B group represented the tap water samples that were added SMX for 6 days; C group represented the tap water samples that were added the chlorinated products of SMX (obtained by solid phase extraction) for 6 days; D group represented the tap water samples that were pretreatment with SMX followed by chlorination for 6 days.

$500 \mathrm{ml}$ of above water samples were concentrated by $0.22 \mu \mathrm{m}$ sterile filter 
membranes until the membrane was clogged to capture bacteria. Then, the membranes were cut up with clean scissors and stored at $-20{ }^{\circ} \mathrm{C}$ in $50 \mathrm{~mL}$ centrifuge tubes. The total DNAs were extracted using an EZNA Water DNA Kit (Omega Bio-tek, Georgia, USA) and the extraction steps followed the manufacturer's instructions. The DNA concentration and purity were determined by $1.5 \%$ agarose gel electrophoresis and spectrophotometer analysis (NanoDrop ND-2000c, Thermo, USA), as previous reported by Chen (Chen \&Zhang 2013).

2.7. DNA quantification by real-time quantitative polymerase chain reaction (qPCR) Two sulfonamide resistance genes (sull and sul2), and an integron gene (intI1, used to reflect the transfer potential of horizontal gene) were selected for quantitative detection by StepOnePlus real-time PCR system (Applied Biosystems, CA, USA). In addition, 16S rRNA was also monitored to reflect relative abundance, and the calculation formula of RAs was: RAs $=$ ARG copies / 16S rRNA copies. The detailed primer information and the procedure of qPCR is shown in Table S2. Following previous research (Chen \&Zhang 2013, Li et al. 2017b), the plasmids containing target genes were obtained by molecular cloning, and plasmids carrying target genes (serially 10-fold dilution) were used to generate standard curves (including 5 or 6 points).

The qPCRs were conducted in 96-well plates with a final volume of $20 \mu \mathrm{L}$ mixture, containing 10 $\mu \mathrm{L}$ SYBR Premix Ex Taq (TaKaRa, Bio, Shiga, Japan), 7.2 $\mu$ L DNA-free water, $2 \mu \mathrm{L}$ template DNA and $0.2 \mu \mathrm{M}$ forward and reverse primers. The temperature procedure was as the following: initial denaturation step for $180 \mathrm{~s}$ at $95{ }^{\circ} \mathrm{C}$ and then 35 cycles of amplification containing denaturation for $30 \mathrm{~s}$ at $94{ }^{\circ} \mathrm{C}$, annealing for $30 \mathrm{~s}$ at 


\section{Results and discussion}

\subsection{Kinetics of SMX degradation}

\subsubsection{Effect of FC}

Fig. 1 (a) and 1 (c) showed the SMX degradation at different free chlorine (0.4-

$1.0 \mathrm{mg} / \mathrm{L}$ ), it can be seen that when $\mathrm{FC} \geq 0.6 \mathrm{mg} / \mathrm{L}$ and reaction time was more than 30 minutes, the SMX was almost completely degraded in both the batch and WDS tests.

However, the degradation of SMX in the batch reactor was faster than that in WDS. At the concentration of $1.0 \mathrm{mg} / \mathrm{L} \mathrm{FC}$, it took about $15 \mathrm{~min}$ for the removal of SMX to reach $100 \%$ in WDS, while only 10 minutes in batch test. In addition, the degradation rate of the two reaction systems increased monotonously with the initial FC concentration increased (Fig. 1 (b) and Fig. 1 (d)). At the concentration of 0.4, 0.6, 0.8, and $1.0 \mathrm{mg} / \mathrm{L}$ of FC, the removal ratio of SMX in batch reactor increased from $52.9 \%$, to $75.3 \%, 100 \%$ and $100 \%$, and in WDS increased from $56.5 \%$, to $66.5 \%, 85.7 \%$ and $92.6 \%$ respectively in $10 \mathrm{~min}$.

[Fig. 1] $\ln \left([\mathrm{SMX}]_{\mathrm{t}} /[\mathrm{SMX}]_{0}\right)$ at different FC concentration, the first-order model was used (Eq. (1)): 
concentration in batch reactor was bigger than those in WDS (Table S3). The difference

262 may have been caused by complex conditions of the WDS, where maybe occurred

263 multiple reactions due to the presences of pipe contains scale (natural organic matter is

264 its component (Lytle \&Liggett 2016)) at the pipe wall (Fig S3), which consumed some

265 FC (Dong et al. 2019). On the contrary, the conditions in the batch reactor were

266 relatively stable, thus the linear correlation in backer tests was better than in WDS.

267 However, the linear correlation in WDS was still satisfactory (all $\mathrm{R}^{2} \geq 0.966$ ), thus the

268 SMX degradation by various initial FC concentrations in both the batch reactor and

269 WDS were followed the first-order kinetics.

270 Previous studies have found that the degradation of Sulfadiazine the pipe network

271 follows a second-order kinetics (Dodd \&Huang 2004, Dong et al. 2019), so this

272 possibility was also studied. The second-order rate kinetics constants $\left(k_{2}\right)$ could be

273 calculated by Eqs. (2) - (3):

274

$$
-\frac{\mathrm{d}[\mathrm{SMX}]_{\mathrm{t}}}{\mathrm{dt}}=k_{2}[\mathrm{FC}][\mathrm{SMX}]_{\mathrm{t}}
$$

$$
k_{2}=\frac{k_{1}}{[\mathrm{FC}]}
$$
the relationship between $k_{2}$ and FC concentration was satisfactory linear correlation in

278 both the batch reactor $\left(\mathrm{R}^{2}=0.995\right)$ and WDS $\left(\mathrm{R}^{2}=0.960\right)$. Therefore, the degradation of SMX in both the batch reactor and WDS also could be described by second-order model. 
In the batch reactor (Fig. 2 (a)), after 40 min, the degradation amount of SMX by

FC remained at $100 \%$ during pH 6.3 to $\mathrm{pH} 7.2$ and decreased from $100 \%$ to $73.08 \%$

during $\mathrm{pH} 7.2$ to $\mathrm{pH}$ 9.0. Fig. 2 (d) showed that the SMX degradation in the WDS and its results were similar to the batch tests, indicating that their highest efficiency of SMX degradation occurred at $\mathrm{pH}$ close to neutral $(\mathrm{pH} \approx 7.0)$. The first-order rate constants $(k)$ of reactions between SMX and FC were obviously dependent on the $\mathrm{pH}$ value, as shown in Fig. 2(b) and Fig. 2(e). As shown in Table S4, the $k$ increased from 0.117 to 0.139 $\mathrm{min}^{-1}$ in batch experiment and from 0.097 to $0.107 \mathrm{~min}^{-1}$ in WDS when the solution $\mathrm{pH}$ value increased from 6.3 to 7.0 ; Yet the $k$ decreased from 0.139 to $0.027 \mathrm{~min}^{-1}$ in increased from 7.0 to 9.0. Therefore, the fastest rate of SMX degradation also occurred at $\mathrm{pH}$ close to neutral. In addition, all $\mathrm{R}^{2}$ of batch experiment were bigger than that of WDS when the set $\mathrm{pH}$ value was similar, and the reason had been discussed in section 3.1.1. and the SMX may be used to explain the $\mathrm{pH}$ dependence behavior in the reaction of FC and SMX.

$$
\mathrm{p} K_{\mathrm{a}}=7.54
$$

$$
\mathrm{HSMX}^{+} f \quad \mathrm{H}^{+}+\mathrm{SMX} \quad \mathrm{p} K_{\mathrm{a} 1}=1.8
$$

$$
\begin{array}{lll}
\mathrm{SMX} f & \mathrm{H}^{+}+\mathrm{SMX}^{-} \quad \mathrm{p} K_{\mathrm{a} 2}=5.6
\end{array}
$$


$\mathrm{HSMX}^{+}, \mathrm{SMX}$, and $\mathrm{SMX}^{-}$) could be considered to react with each other, thus the dependence of $\mathrm{k}_{\mathrm{app}}$ on solution $\mathrm{pH}$ can be modeled by Eqs. (7) - (8):

$$
-\frac{\mathrm{d}[\mathrm{SMX}]_{\mathrm{all}}}{\mathrm{d}_{\mathrm{t}}}=\mathrm{k}_{\mathrm{app}}[\mathrm{SMX}]_{\mathrm{all}}[\mathrm{FC}]_{\mathrm{all}}=\sum_{\mathrm{i}=1,2, \mathrm{j}=1,2,3} \mathrm{k}_{\mathrm{ij}} \alpha_{\mathrm{i}} \beta_{\mathrm{j}}[\mathrm{SMX}]_{\mathrm{all}}[\mathrm{FC}]_{\mathrm{all}}
$$

$$
\mathrm{k}_{\mathrm{app}}=\sum_{\mathrm{i}=1,2, \mathrm{j}=1,2,3} \mathrm{k}_{\mathrm{ij}} \alpha_{\mathrm{i}} \beta_{\mathrm{j}}
$$

$$
\text { Where }[\mathrm{FC}]_{\mathrm{all}}=[\mathrm{HClO}]+\left[\mathrm{ClO}^{-}\right] ;[\mathrm{SMX}]_{\mathrm{all}}=\left[\mathrm{HSMX}^{+}\right]+[\mathrm{SMX}]+\left[\mathrm{SMX}^{-}\right] ; \mathrm{k}_{\mathrm{i}, \mathrm{j}} \text { is }
$$
and $[\mathrm{SMX}]_{\text {all }}$ species, respectively, and they can be calculated at different $\mathrm{pH}$ by the following equation (Eqs. (9)-(13)):

$$
\alpha_{1}=[\mathrm{HClO}] /[\mathrm{FC}]_{\mathrm{all}}=\left[\mathrm{H}^{+}\right] /\left(\left[\mathrm{H}^{+}\right]+10^{-7.54}\right)
$$

$$
\alpha_{2}=\left[\mathrm{ClO}^{-}\right] /[\mathrm{FC}]_{\text {all }}=10^{-7.54} /\left(\left[\mathrm{H}^{+}\right]+10^{-7.54}\right)
$$

$$
\beta_{1}=\left[\mathrm{HSMX}^{+}\right] /[\mathrm{SMX}]_{a l}=\left(\left[\mathrm{H}^{+}\right]\right)^{2} /\left(\left(\left[\mathrm{H}^{+}\right]\right)^{2}+\left[\mathrm{H}^{+}\right] * 10^{-1.8}+10^{-1.8} * 10^{-5.6}\right)
$$

$$
\beta_{2}=[\mathrm{SMX}] /[\mathrm{SMX}]_{\text {al }}=\left(\left[\mathrm{H}^{+}\right] * 10^{-1.8}\right) /\left(\left(\left[\mathrm{H}^{+}\right]\right)^{2}+\left[\mathrm{H}^{+}\right] * 10^{-1.8}+10^{-1.8} * 10^{-5.6}\right)
$$

$$
\beta_{3}=\left[\mathrm{SMX} \mathbf{X}^{-}\right] /[\mathrm{SMX}]_{\mathrm{all}}=\left(10^{-1.8} * 10^{-5.6}\right) /\left(\left(\left[\mathrm{H}^{+}\right]\right)^{2}+\left[\mathrm{H}^{+}\right] * 10^{-1.8}+10^{-1.8} * 10^{-5.6}\right)
$$
experimental $\mathrm{k}_{\mathrm{app}}$ according to the Eq. (8), using MATLAB. While there were six possible reactions from the Eq. (8), fitting of the experimental data of Fig. 2 (c) and Fig. 2 (f) showed that only following two reactions (Eqs. (14) - (15)) could reasonably fit the experimental data (a solid line), $\mathrm{R}^{2} \geq 0.974$ and $\mathrm{R}^{2} \geq 0.972$ in batch reactor and WDS, respectively. The reason for this may be that $\left[\mathrm{HSMX}^{+}\right]$and $[\mathrm{SMX}]$ have little effect in the reaction system due to their extremely low mole fraction at $\mathrm{pH} 6.3-9.0$ 
is also shown in Fig. 2(c) and Fig. 2(f) (dashed lines). This result indicated that the $\mathrm{HClO}$ reacts faster with deprotonated $\mathrm{SMX}\left(\mathrm{SMX}^{-}\right)$than $\mathrm{HClO}^{-}$(i.e., in batch reactor: $\mathrm{k}_{13}=(2.23 \pm 0.07) \times 10^{2}>\mathrm{k}_{23}=(5.04 \pm 0.30) \times 10^{1} \mathrm{M}^{-} \mathrm{s}^{-} ;$in WDS: $\mathrm{k}_{13}=(1.76 \pm 0.07)$ $\left.\times 10^{2} \mathrm{M}>\mathrm{k}_{23}=(4.06 \pm 0.62) \times 10^{1} \mathrm{M}^{-} \mathrm{s}^{-}\right)$. At $\mathrm{pH} 6.3-8.2$, reaction (14) mainly contributed to the $\mathrm{k}_{\mathrm{app}}$. In contrast, the $\mathrm{k}_{\mathrm{app}}$ at $\mathrm{pH}$ from 8.2 to 9.0 could be attributed to reaction (15). At nearly neutral $\mathrm{pH}$, the comprehensive effect of reaction (14) and reaction (15) is the best, the subsequent experiments can thus be carried out at a nearly neutral $\mathrm{pH}$.

\subsubsection{Effect of flow rate}

[Fig. 3]

As shown in Fig. 3, the change of flow rate had little effect on the SMX degradation. The degradation rate constants for SMX were $0.129,0.190,0.211$ and $0.201 \mathrm{~min}^{-1}$ under the condition of $0.7,1.0,1.3$ and $1.5 \mathrm{~m} / \mathrm{s}$, respectively (Table. S5). The possible reason for this difference is that flow rate could change the hydraulic conditions in WDS, thereby affecting mass transfer coefficient. The Reynolds number (Re) was used to evaluate this behavior, $R_{\mathrm{e}}=\rho v \mathrm{~d} / \mu$, where $\rho, v, \mathrm{~d}$ and $\mu$ represent the density, flow rate, pipe diameter and viscosity coefficient of fluid $\left(0.895 \times 10^{-3} \mathrm{~Pa} \cdot \mathrm{s}\right.$, $25^{\circ} \mathrm{C}$ ), respectively. All Re more than 4300 (Table. S5), indicating that turbulent flow conditions exist in WDS. Mass transfer coefficient increased with increasing Re under turbulent flow conditions, ultimately improves mixing and this may make the rate of 
SMX degradation enhanced when the flow rate from 0.7 to $1.0 \mathrm{~m} / \mathrm{s}$. However, when the flow rate from 1.0 to $1.5 \mathrm{~m} / \mathrm{s}$, the degradation rate hardly increased because the effect of mass transfer on degradation has reached the limit.

\subsubsection{Effect of pipe materials}

[Fig. 4]

As shown in Fig. 4, after 15min of reaction, the removal of SMX reached 100\%, $87.8 \%$ and $94.4 \%$ in the PE, DI and SS, respectively. Table S6 summarized the calculated first-order rate constants, these data showed that the order of degradation rate was $\mathrm{SS}\left(0.358 \mathrm{~min}^{-1}\right)>\operatorname{DI}\left(0.191 \mathrm{~min}^{-1}\right)>\operatorname{PE}\left(0.139 \mathrm{~min}^{-1}\right)$. Metal ions and corroded metal might contribute to this phenomenon, DI were better protected because they have lined with a layer of cement, but SS is more prone to rust due to poor welding (Dong et al. 2017). Consequently, compared with DI and PE, the SS has the most metal ions and corroded metal. As discussed in the section 3.1.3, when the flow rate was 1.0 $\mathrm{m} / \mathrm{s}$, these experiments were conducted with turbulent flows $(\operatorname{Re}>4300)$, consequently, the metal ions and corroded metal in solder joints were easily transferred to the water. The concentrations of total iron in the three pipes were detected, which was $0.8 \mathrm{mg} / \mathrm{L}$ in $\mathrm{SS}$ and less than $0.1 \mathrm{mg} / \mathrm{L}$ in $\mathrm{DI}$ and $\mathrm{PE} . \mathrm{Fe}^{2+}$ could be oxidized to $\mathrm{Fe}^{3+}$ by $\mathrm{FC}$, and the process produced some free radicals that enhanced the SMX degradation (Dong et al. 2019, Perez-Moya et al. 2010). In addition, $\mathrm{Fe}^{3+}$ might be oxidized to higher valence iron in hypochlorite solution system, such as a way to prepare ferrate (VI) is to oxidize $\mathrm{Fe}^{3+}$ with sodium hypochlorite solution under alkaline condition ( $\mathrm{Li}$ et al. 2005). The 
higher valence iron has stronger oxidize ability and it could promote the degradation of SMX.

\subsection{Toxicity assessment of SMX degradation}

[Fig. 5]

As shown in Fig. 5, compared with the inhibition of bioluminescence rate of tap water close to 0 , the presence of SMX can significantly increase the toxicity of water. In the first $10 \mathrm{~min}$ of reaction, with the degradation of SMX, the toxicity showed a downward trend. Within 10 to 90 minutes of the reaction, the toxicity showed an upward trend, indicating that the intermediate products of the reaction were also toxic. However, within 90 to 120 minutes of the reaction, the toxicity showed a downward trend until it was the same as that of tap water, which indicated that SMX could be completely degraded by FC within 2 hours, and the toxicity of chlorinated products was low.

\subsection{Generation of ARGs in WDS}

[Fig. 6]

The comparison of ARGs contents and relative abundance of water samples under different treatments are shown in Figure 6. In general, compared with group A, the number and relative abundance of sull, sul2 and intIl genes in group B, C and D were significantly increased. However, the number of 16S rRNA did not change significantly, indicates that the total number of bacteria changed little. Previous studies have shown that the variation of ARGs relative abundance is mainly caused by two aspects: one is the change of host bacteria abundance and the other is the horizontal transfer of ARGs 
in bacteria (Jia et al. 2015, Su et al. 2015), and the increase of ARGs in drinking water was the result of two factors (Jia et al. 2015). Therefore, the following analysis mainly consider these two aspects.

In group B, although the total number of bacteria decreased slightly, the number of sull and sul2 increased. This may have been caused SMX inhibited the growth of other bacteria and promoted the increase of antibiotic-resistant bacterial community. In addition, SMX as an environmental pressure, could promote the replication of sull and sul2, which was the main reason for the increase of sull and sul2. On the other hand, the increase of sull and sul2 was also caused by the transfer of ARGs (because the number of intIl has increased). In group C, the increase of 16S rRNA genes number reflected the increase of total bacterial count, indicating that chlorination products had no inhibitory effect on total bacterial count. These results showed that even if SMX was chlorinated in water, its chlorination products would still lead to the production of resistance genes. The reason may be that chlorination cannot completely open the aromatic ring in SMX molecule, some products can only replace one $\mathrm{H}$ atom by the electrophilic reaction of chlorine to form Cl-SMX, which may also have the properties of sulfonamide antibiotics.

High concentration of FC ( $>10 \mathrm{mg} / \mathrm{L})$ can effectively degrade the concentration of ARGs in the water environment (Zhang et al. 2015b), but the results of group D under the experimental conditions of low concentration of FC are opposite, and the same results were observed in the study of Jia (Jia et al. 2015) and Shi (Shi et al. 2013). The reason is that under the condition of high FC value, FC can directly kill bacteria, while 
under the condition of low FC value, the growth of non-chlorine resistant bacteria is inhibited, and chlorine resistant bacteria can not only survive, but also increase the copy number and relative abundance of ARGs through gene replication. Our team has found that Pseudomonas and Mycobacterium are the main bacterium in the WDS (Zhang et al. 2018a), which has the function of chlorine resistance. Pseudomonas is the host bacteria of the trans ARGs (Zhang et al. 2019), and its growth and replication will lead to the change of its relative abundance and quantity, which will lead to the increase of the relative abundance and copy number of sull and sul2. In addition, under the external pressure of active chlorine, the permeability of bacterial cell membrane changes, and the frequency of intI1 binding and transferring ARGs increases. However, the probability of binding and transferring ARGs is small when the bacteria in pipe network are less than $10000 \mathrm{CFU} / \mathrm{ml}$ (Guo et al. 2015a), so the number and relative abundance of ARGs are also affected by the external pressure of active chlorine, but its contribution rate is low. ARGs in group $\mathrm{C}$ increased more than that in other groups, this suggests that the chlorinated products of SMX can promote the production of ARGs in WDS (DI), but what chlorination products caused the increase needs to be further studied.

\section{Conclusion}

(1) The degradation rate of SMX in batch reactor was faster than that in WDS, and the rate was positive correlation with the initial concentration of FC.

(2) Whether in batch reactor or WDS, the SMX chlorination could be described by the first or the second-order kinetics. 
(3) When the $\mathrm{pH}$ value was from 6.3 to 9.0 , the degradation efficiency of SMX

435 first increased and then decreased, and the efficiency reached a maximum at nearly

436 neutral $\mathrm{pH}$. In addition, the fastest rate of SMX degradation also occurred at $\mathrm{pH}$ close

437 to neutral, and the relationship between the second-order rate constants and $\mathrm{pH}$ values

438 were explained by using the species-specific rate constants of FC with SMX.

439 (4) Under different pipe materials conditions, the SMX degradation rate followed

440 the order: $\mathrm{SS}>\mathrm{DI}>\mathrm{PE}$, and high flow rate led to the rate increased in DI, but the 441 increase was limited.

442 (5) SMX could increase the toxicity of water initially, but the toxicity reduced 443 after 2 hours chlorination.

444 (6) The chlorination products of SMX can significantly promote the production of 445 ARGs in WDS (DI), but which chlorination products lead to the increase remains to be 446 further studied. 
Barhoumi N, Oturan N, Olvera-Vargas H, Brillas E, Gadri A, Ammar S, Oturan MA (2016): Pyrite as a sustainable catalyst in electro-Fenton process for improving oxidation of sulfamethazine. Kinetics, mechanism and toxicity assessment. Water Research 94, 52-61

Beltran FJ, Aguinaco A, Garcia-Araya JF, Oropesa AL (2008): Ozone and photocatalytic processes to remove the antibiotic sulfamethoxazole from water. Water Research 42, 3799-3808

Buysse DJ, Reynolds CF, 3rd, Monk TH, Berman SR, Kupfer DJ (1989): The Pittsburgh Sleep Quality Index: a new instrument for psychiatric practice and research. Psychiatry research 28, 193-213

Chen H, Gao B, Li H, Ma LQ (2011): Effects of pH and ionic strength on sulfamethoxazole and ciprofloxacin transport in saturated porous media. J. Contam. Hydrol. 126, 29-36

Chen H, Zhang MM (2013): Effects of Advanced Treatment Systems on the Removal of Antibiotic Resistance Genes in Wastewater Treatment Plants from Hangzhou, China. Environmental Science \& Technology 47, 8157-8163

Chen JF, Xie SG (2018): Overview of sulfonamide biodegradation and the relevant pathways and microorganisms. Sci. Total Environ. 640, 1465-1477

Chen KL, Liu LC, Chen WR (2017): Adsorption of sulfamethoxazole and sulfapyridine antibiotics in high organic content soils. Environ. Pollut. 231, 1163-1171

Choi KJ, Kim SG, Kim SH (2008): Removal of tetracycline and sulfonamide classes of antibiotic compound by powdered activated carbon. Environmental Technology 29, $333-342$

Choquet-Kastylevsky G, Vial T, Descotes J (2002): Allergic adverse reactions to sulfonamides. Current allergy and asthma reports 2, 16-25

Dodd MC, Huang CH (2004): Transformation of the antibacterial agent sulfamethoxazole in reactions with chlorine: Kinetics mechanisms, and pathways. Environmental Science \& Technology 38, 5607-5615

Dong FL, Li C, He GL, Chen XB, Mao XW (2017): Kinetics and degradation pathway of sulfamethazine chlorination in pilot-scale water distribution systems. Chemical Engineering Journal 321, 521-532

Dong FL, Li C, Crittenden J, Zhang TQ, Lin QF, He GL, Zhang WQ, Luo JM (2019) : Sulfadiazine destruction by chlorination in a pilot-scale water distribution system: Kinetics, pathway, and bacterial community structure. J. Hazard. Mater. 366, 88-97

Fent K, Weston AA, Caminada D (2006) : Ecotoxicology of human pharmaceuticals. Aquatic Toxicology 76, 122-159

Gaffney VD, Cardoso VV, Benoliel MJ, Almeida CMM (2016): Chlorination and oxidation of sulfonamides by free chlorine: Identification and behaviour of reaction products by UPLC-MS/MS. J. Environ. Manage. 166, 466-477

Gobel A, Thomsen A, McArdell CS, Joss A, Giger W (2005): 0ccurrence and sorption 
behavior of sulfonamides, macrolides, and trimethoprim in activated sludge treatment. Environmental Science \& Technology 39, 3981-3989

Gulkowska A, Leung HW, So MK, Taniyasu S, Yamashita N, Yeunq LWY, Richardson BJ, Lei AP, Giesy JP, Lam PKS (2008): Removal of antibiotics from wastewater by sewage treatment facilities in Hong Kong and Shenzhen, China. Water Research 42, 395-403

Guo MT, Yuan QB, Yang J (2015a): Distinguishing Effects of Ultraviolet Exposure and Chlorination on the Horizontal Transfer of Antibiotic Resistance Genes in Municipal Wastewater. Environmental Science \& Technology 49, 5771-5778

Guo WQ, Yin RL, Zhou XJ, Du JS, Cao H0, Yang SS, Ren NQ (2015b): Sulfamethoxazole degradation by ultrasound/ozone oxidation process in water: Kinetics, mechanisms, and pathways. U1trason. Sonochem. 22, 182-187

Guo XP, Li J, Yang F, Yang J, Yin DQ (2014): Prevalence of sulfonamide and tetracycline resistance genes in drinking water treatment plants in the Yangtze River Delta, China. Sci. Total Environ. 493, 626-631

Huang JS, Zimmerman AR, Chen H, Gao B (2020): Ball milled biochar effectively removes sulfamethoxazole and sulfapyridine antibiotics from water and wastewater. Environ. Pollut. 258, 7

Jeong J, Song WH, Cooper WJ, Jung J, Greaves J (2010): Degradation of tetracycline antibiotics: Mechanisms and kinetic studies for advanced oxidation/reduction processes. Chemosphere 78, 533-540

Jia SY, Shi P, Hu Q, Li B, Zhang T, Zhang XX (2015): Bacterial Community Shift Drives Antibiotic Resistance Promotion during Drinking Water Chlorination. Environmental Science \& Technology 49, 12271-12279

Jiang L, Hu XL, Yin DQ, Zhang HC, Yu ZY (2011): Occurrence, distribution and seasonal variation of antibiotics in the Huangpu River, Shanghai, China. Chemosphere $82,822-828$

Li C, Li XZ, Graham N (2005): A study of the preparation and reactivity of potassium ferrate. Chemosphere 61, 537-543

Li N, Ho KWK, Ying GG, Deng WJ (2017a): Veterinary antibiotics in food, drinking water, and the urine of preschool children in Hong Kong. Environ. Int. 108, 246-252

Li N, Sheng GP, Lu YZ, Zeng RJ, Yu HQ (2017b): Removal of antibiotic resistance genes from wastewater treatment plant effluent by coagulation. Water Research 111, 204-212

Lindberg R, Jarnheimer PA, 01sen B, Johansson M, Tysklind M (2004): Determination of antibiotic substances in hospital sewage water using solid phase extraction and liquid chromatography/mass spectrometry and group analogue internal standards. Chemosphere 57, 1479-1488

Luo Y, Xu L, Rysz M, Wang YQ, Zhang H, Alvarez PJJ (2011): Occurrence and Transport of Tetracycline, Sulfonamide, Quinolone, and Macrolide Antibiotics in the Haihe River Basin, China. Environmental Science \& Technology 45, 1827-1833

Lytle DA, Liggett J (2016): Impact of water quality on chlorine demand of corroding copper. Water Research 92, 11-21 
Migliore L, Cozzolino S, Fiori M (2003): Phytotoxicity to and uptake of enrofloxacin in crop plants. Chemosphere 52, 1233-1244

Mulvey MR, Simor AE (2009): Antimicrobial resistance in hospitals: How concerned should we be? Canadian Medical Association Journal 180, 408-415

Nassar R, Mokh S, Rifai A, Chamas F, Hoteit M, Al Iskandarani M (2018): Transformation of sulfaquinoxaline by chlorine and UV light in water: kinetics and by-product identification. Environ. Sci. Pollut. Res. 25, 34863-34872

Peiris C, Gunatilake SR, Mlsna TE, Mohan D, Vithanage M (2017): Biochar based removal of antibiotic sulfonamides and tetracyclines in aquatic environments: A critical review. Bioresour. Technol. 246, 150-159

Perez-Moya M, Graells M, Castells G, Amigo J, Ortega E, Buhigas G, Perez LM, Mansilla HD (2010): Characterization of the degradation performance of the sulfamethazine antibiotic by photo-Fenton process. Water Research 44, 25332540

Qiu J, Zhao T, Liu Q, He J, He D, Wu G, Li Y, Jiang C, Xu Z (2016): Residual veterinary antibiotics in pig excreta after oral administration of sulfonamides. Environmental Geochemistry and Health 38, 549-556

Rosman N, Salleh WNW, Mohamed MA, Jaafar J, Ismail AF, Harun Z (2018): Hybrid membrane filtration-advanced oxidation processes for removal of pharmaceutical residue. Journal of Colloid and Interface Science 532, 236-260

Shao B, Dong D, Wu YN, Hu JY, Meng J, Tu XM, Xu SK (2005): Simultaneous determination of 17 sulfonamide residues in porcine meat, kidney and liver by solid-phase extraction and liquid chromatography-tandem mass spectrometry. Analytica Chimica Acta 546, 174-181

Shi P, Jia SY, Zhang XX, Zhang T, Cheng SP, Li AM (2013): Metagenomic insights into chlorination effects on microbial antibiotic resistance in drinking water. Water Research 47, 111-120

Stoll C, Sidhu JPS, Tiehm A, Toze S (2012): Prevalence of Clinically Relevant Antibiotic Resistance Genes in Surface Water Samples Collected from Germany and Australia. Environmental Science \& Technology 46, 9716-9726

Su JQ, Wei B, Ou-Yang WY, Huang FY, Zhao Y, Xu HJ, Zhu YG (2015) : Antibiotic Resistome and Its Association with Bacterial Communities during Sewage Sludge Composting. Environmental Science \& Technology 49, 7356-7363

Tian Y, Gao B, Morales VL, Chen H, Wang Y, Li H (2013): Removal of sulfamethoxazole and sulfapyridine by carbon nanotubes in fixed-bed columns. Chemosphere 90, 2597-2605

Wang B, Yan JQ, Li GM, Zhang J, Zhang LH, Li Z, Chen HH (2020): Risk of penicillin fermentation dreg: Increase of antibiotic resistance genes after soil discharge. Environ. Pollut. 259, 8

Wei MC, Wang KS, Hsiao TE, Lin IC, Wu HJ, Wu YL, Liu PH, Chang SH (2011): Effects of UV irradiation on humic acid removal by ozonation, Fenton and Fe-0/air treatment: THMFP and biotoxicity evaluation. J. Hazard. Mater. 195, 324-331

Yang WB, Zheng FF, Xue XX, Lu YP (2011): Investigation into adsorption mechanisms of sulfonamides onto porous adsorbents. Journal of Colloid and Interface Science 
362, 503-509

Yao Y, Zhang Y, Gao B, Chen RJ, Wu F (2018): Removal of sulfamethoxazole (SMX) and sulfapyridine (SPY) from aqueous solutions by biochars derived from anaerobically digested bagasse. Environ. Sci. Pollut. Res. 25, 25659-25667

Yu ZH, Zhang XB, Ngo HH, Guo WS, Wen HT, Deng LJ, Li YJ, Guo JB (2018): Removal and degradation mechanisms of sulfonamide antibiotics in a new integrated aerobic submerged membrane bioreactor system. Bioresour. Technol. 268, 599-607

Zhang J, Lin H, Ma JW, Sun WC, Yang YY, Zhang X (2019): Compost-bulking agents reduce the reservoir of antibiotics and antibiotic resistance genes in manures by modifying bacterial microbiota. Sci. Total Environ. 649, 396-404

Zhang KJ, Cao C, Zhou XY, Zheng FF, Sun YM, Cai ZQ, Fu J (2018a): Pilot investigation on formation of 2,4,6-trichloroanisole via microbial 0 -methylation of 2,4,6trichlorophenol in drinking water distribution system: An insight into microbial mechanism. Water Research 131, 11-21

Zhang QQ, Ying GG, Pan CG, Liu YS, Zhao JL (2015a): Comprehensive Evaluation of Antibiotics Emission and Fate in the River Basins of China: Source Analysis, Multimedia Modeling, and Linkage to Bacterial Resistance. Environmental Science \& Technology 49, 6772-6782

Zhang TQ, Dong FL, Luo F, Li C (2018b): Degradation of sulfonamides and formation of trihalomethanes by chlorination after pre-oxidation with Fe(VI). J. Environ. Sci. 73, 89-95

Zhang YY, Zhuang Y, Geng JJ, Ren HQ, Zhang Y, Ding LL, Xu K (2015b): Inactivation of antibiotic resistance genes in municipal wastewater effluent by chlorination and sequential UV/chlorination disinfection. Sci. Total Environ. 512, 125132

Zheng J, Su C, Zhou JW, Xu LK, Qian YY, Chen H (2017): Effects and mechanisms of ultraviolet, chlorination, and ozone disinfection on antibiotic resistance genes in secondary effluents of municipal wastewater treatment plants. Chemical Engineering Journal 317, 309-316 
Figures
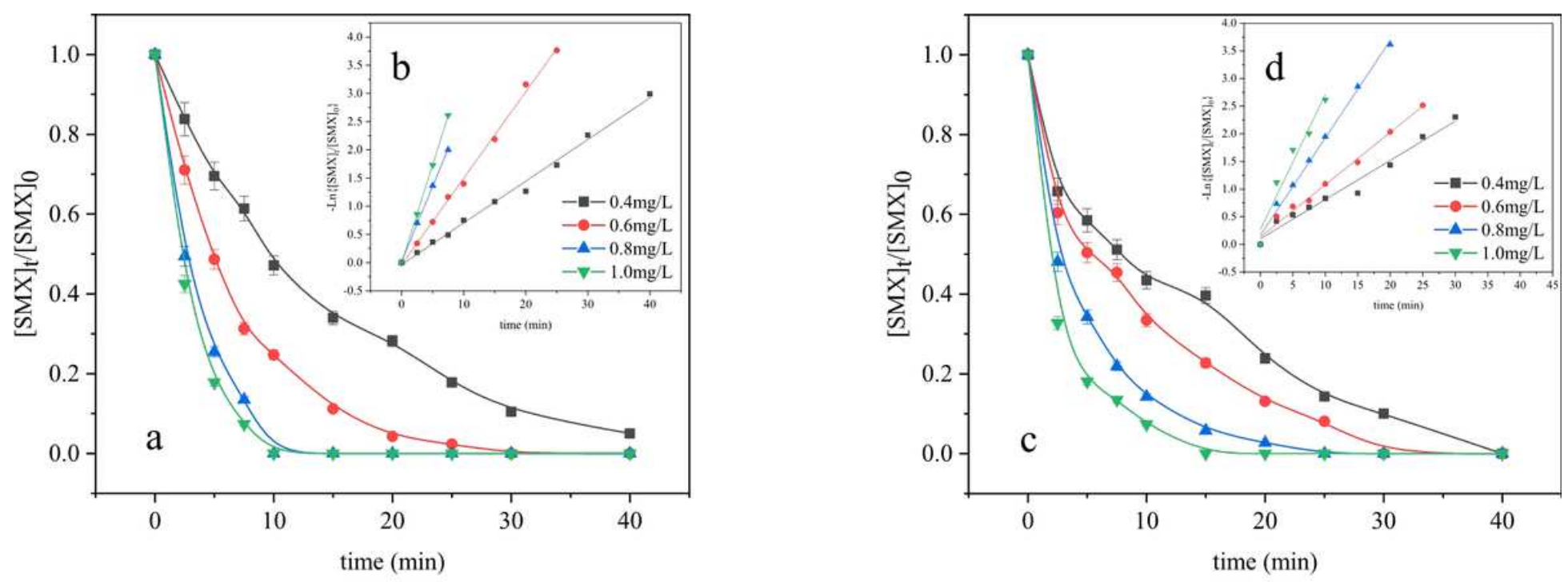

Figure 1

Degradation of SMX at different chlorine concentration in batch reactor (a) and WDS (c), and the firstorder kinetics plot of SMX degradation in batch reactor (b) and WDS (d). Experimental conditions: ductile iron pipe, $25 \otimes, \mathrm{pH}=7.0 \pm 0.2$, flow rate $=1.0 \mathrm{~m} / \mathrm{s}$, initial $\mathrm{SMX}=200 \mu \mathrm{g} / \mathrm{L}$. 

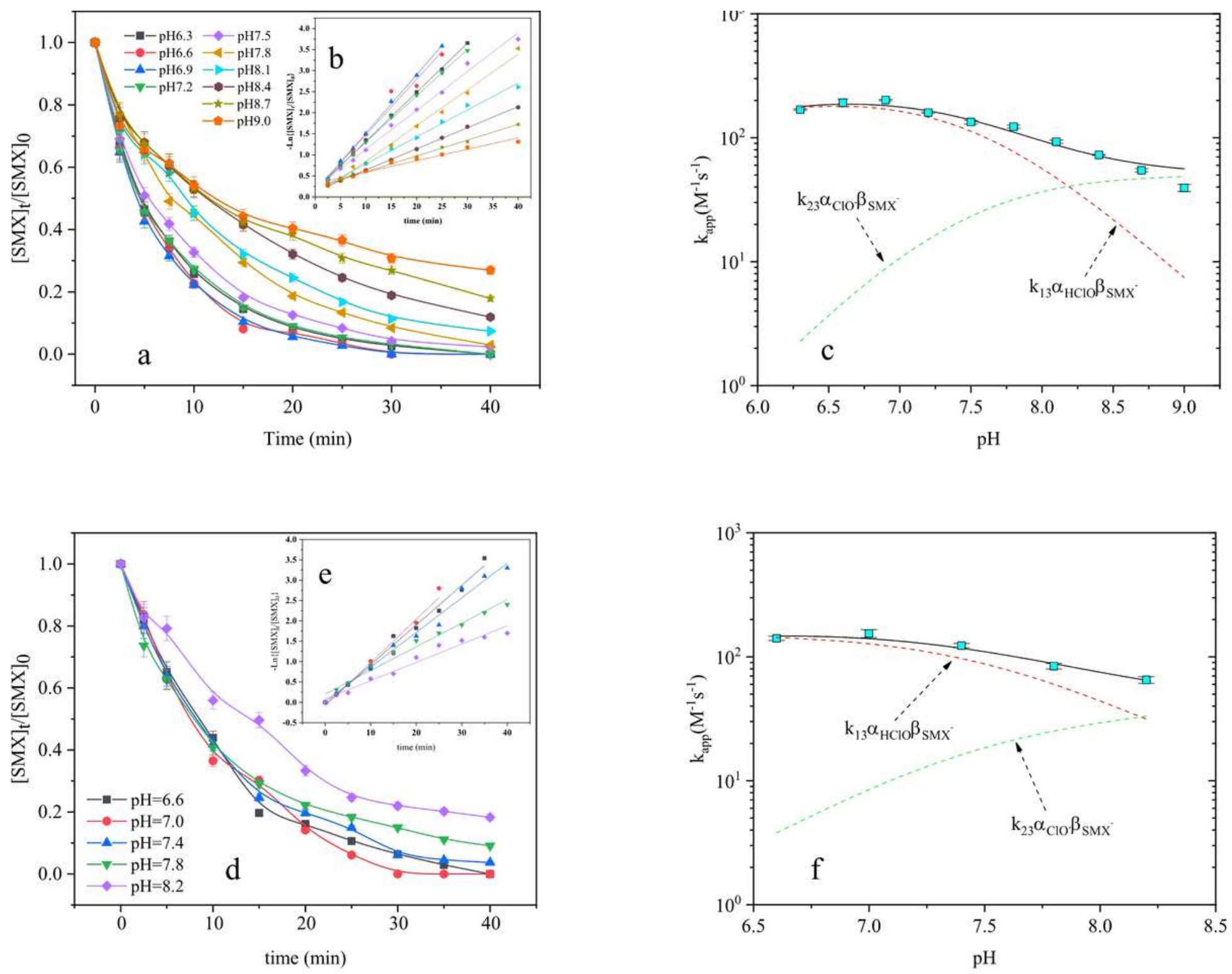

Figure 2

Degradation of SMX at different pH in batch reactor (a) and WDS (d), and the first-order kinetics plot of SMX degradation in batch reactor (b) and WDS (e), and the second-order rate constants (kapp, M-1s-1) as a function of $\mathrm{pH}$ for the SMX chlorination by FC in batch reactor(c) and WDS(f). Experimental

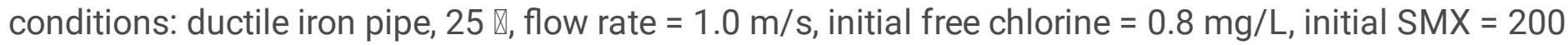
$\mu \mathrm{g} / \mathrm{L}$. 


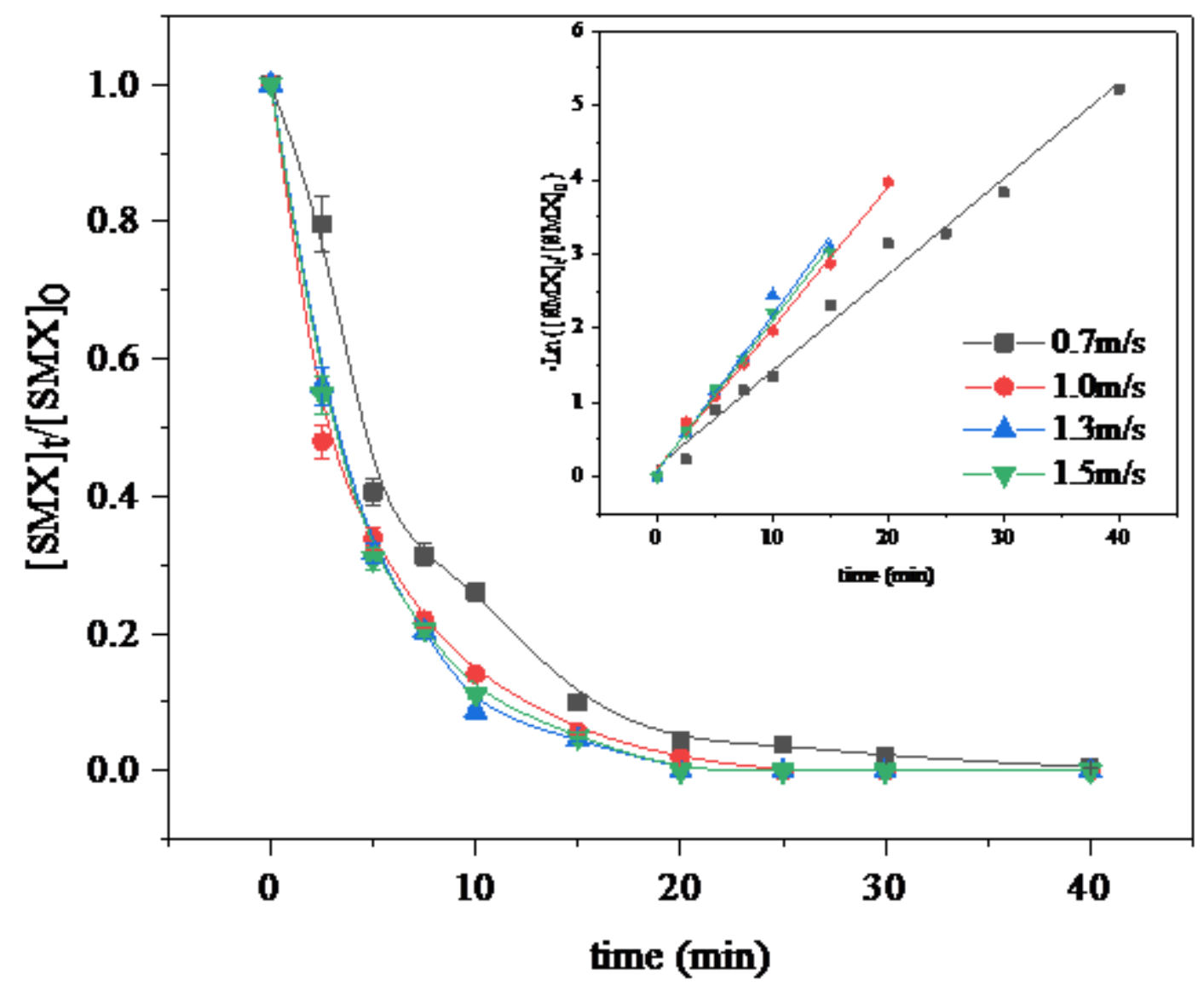

Figure 3

Degradation of SMX at different flow rates in WDS. Experimental conditions: ductile iron pipe, $25 \otimes, \mathrm{pH}=$ $7.0 \pm 0.2$, initial free chlorine $=0.8 \mathrm{mg} / \mathrm{L}$, initial $\mathrm{SMX}=200 \mu \mathrm{g} / \mathrm{L}$. 


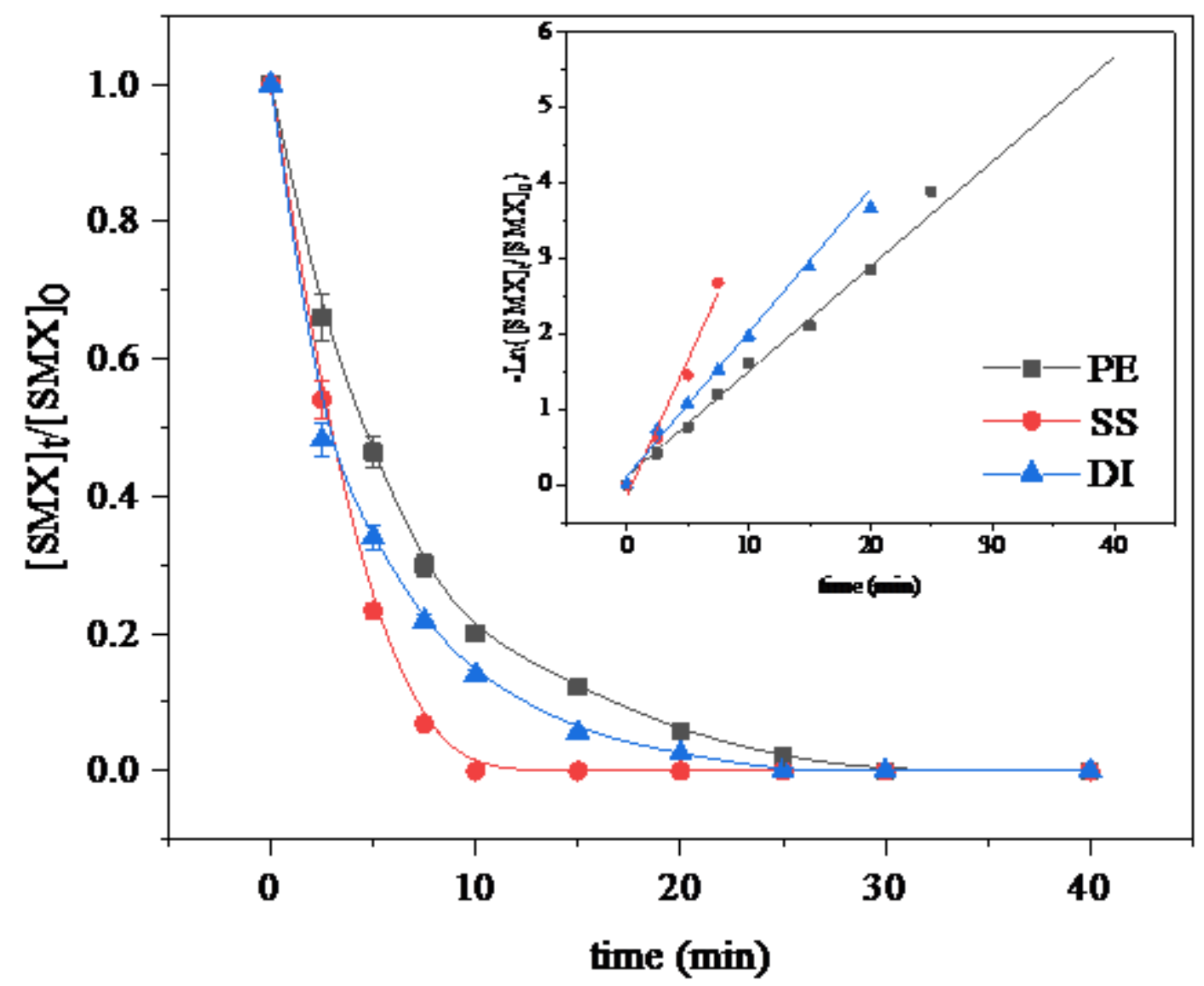

Figure 4

Degradation of SMX in different pipe materials (Polyethylene (PE), ductile iron (DI) and stainless-steel (SS)). Experimental conditions: $25 \otimes, \mathrm{pH}=7.0 \pm 0.2$, flow rate $=1.0 \mathrm{~m} / \mathrm{s}$, initial free chlorine $=0.8 \mathrm{mg} / \mathrm{L}$, initial SMX $=200 \mu \mathrm{g} / \mathrm{L}$. 


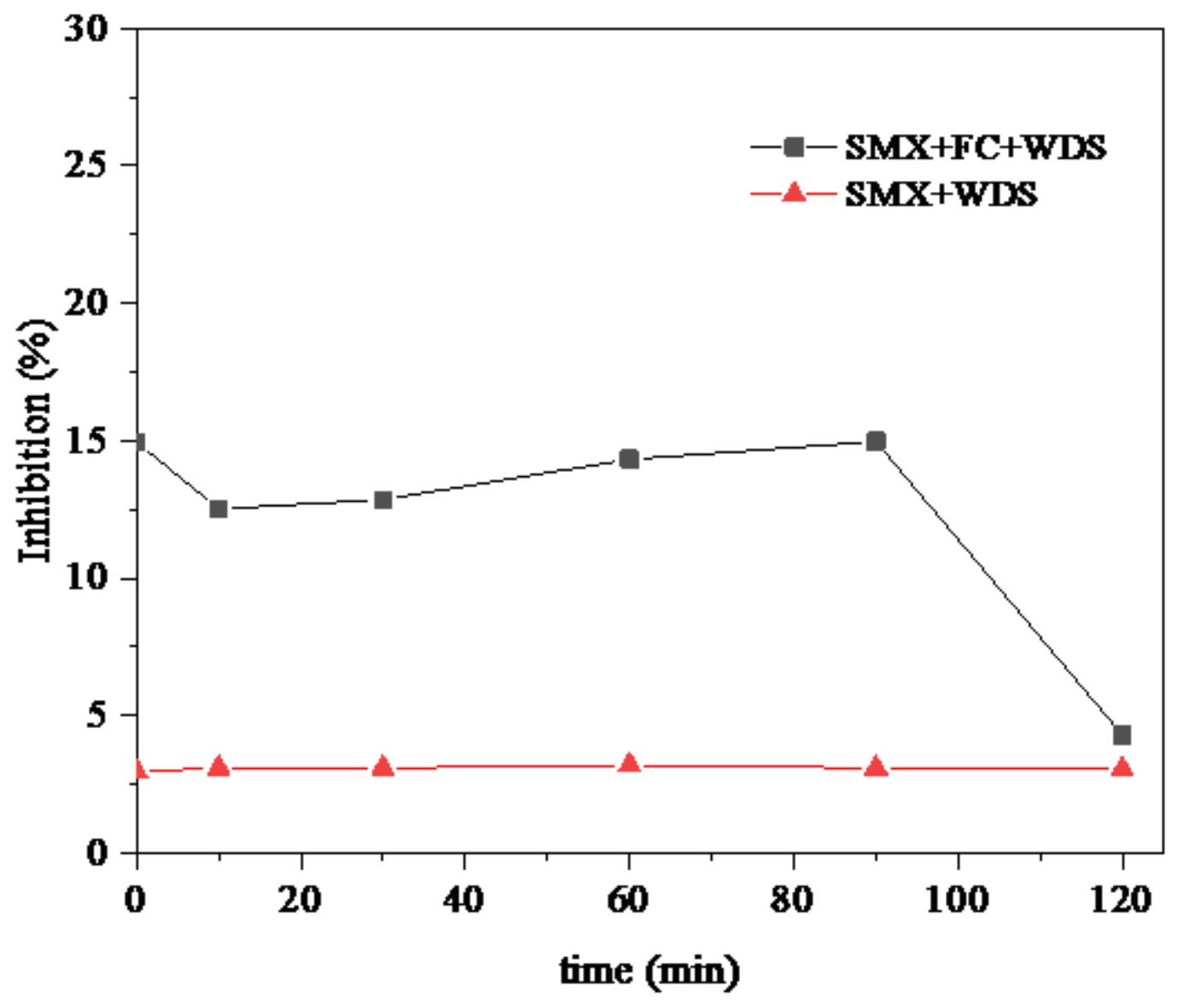

Figure 5

Evolution of toxicity of SMX chlorination. Experimental conditions: ductile iron pipe, $25 \otimes, \mathrm{pH}=7.0 \pm 0.2$, flow rate $=1.0 \mathrm{~m} / \mathrm{s}$, initial free chlorine $=0.8 \mathrm{mg} / \mathrm{L}$, initial SMX $=200 \mu \mathrm{g} / \mathrm{L}$. 


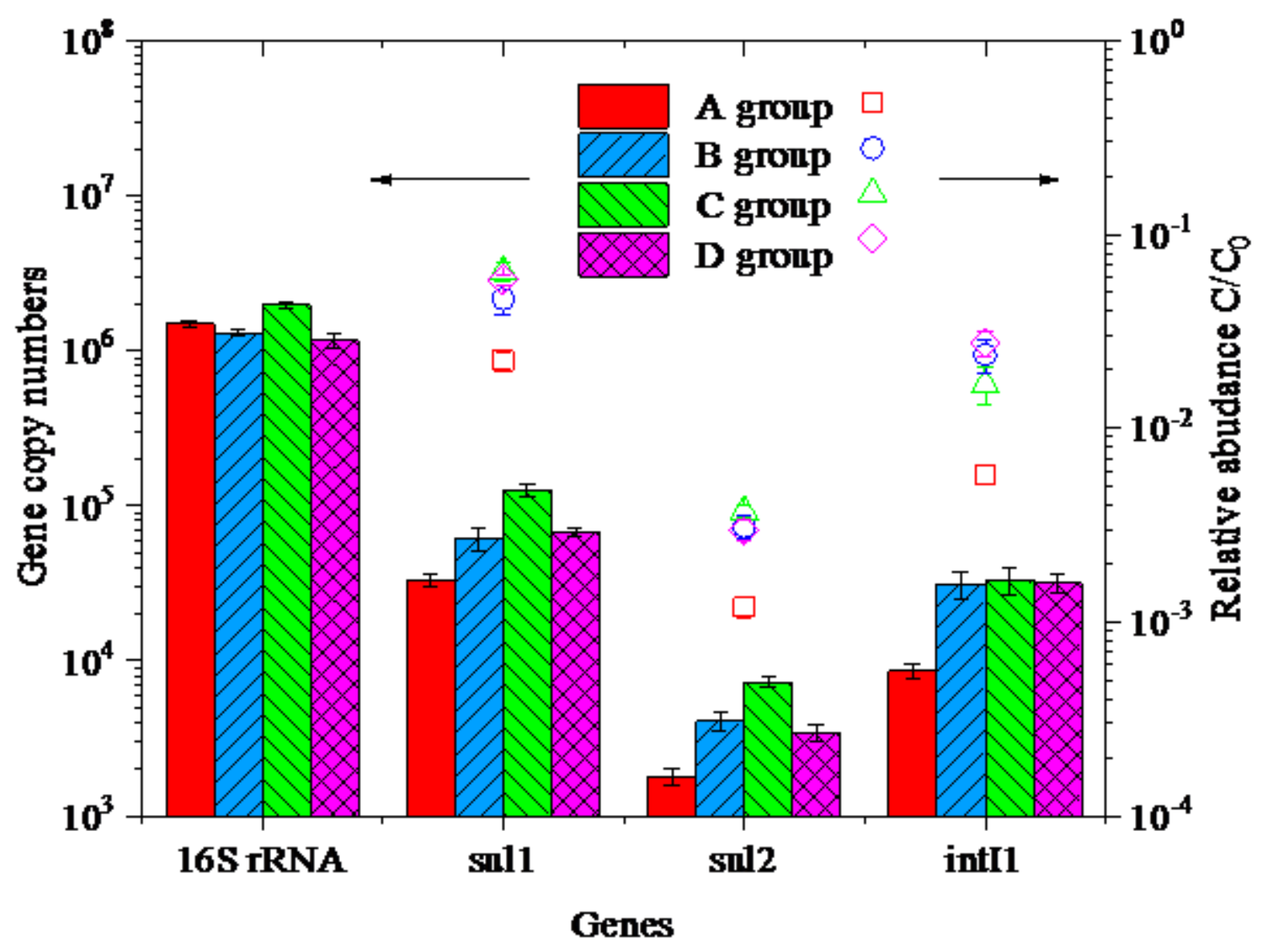

Figure 6

Gene copy numbers and relative abundance of antibiotic resistance genes in different treatment conditions.

\section{Supplementary Files}

This is a list of supplementary files associated with this preprint. Click to download.

- Supportinginformation.docx 